\title{
EDUKASI PERILAKU CUCI TANGAN PAKAI SABUN PADA SISWA UNTUK PENCEGAHAN TRANSMISI PENYAKIT
}

\author{
Grace Tedy Tulak ${ }^{1}$, Syahrul Ramadhan ${ }^{2}$, Alimatul Musrifah ${ }^{3}$ \\ ${ }^{1}$ Fakultas Sains dan Teknologi, Universitas Sembilanbelas November Kolaka, Indonesia \\ ${ }^{2,3}{ }^{3}$ TIKES Kurnia Jaya Persada Palopo, Indonesia \\ 'gracelavianni@gmail.com, ${ }^{2}$ madankjp37@gmail.com, ${ }^{3}$ alimatulkjp28@gmail.com
}

\begin{abstract}
ABSTRAK
Abstrak: Anak usia sekolah mempunyai kebiasaan kurang memperhatikan perilaku mencuci tangan terutama di lingkungan sekolah. Kebiasaan Cuci Tangan Pakai Sabun (CTPS) masih menjadi perhatian dunia karena masih ditemukan masyarakat yang melupakan perilaku mencuci tangan. Fokus kegiatan CTPS adalah anak usia sekolah yang menjadi "Agen Perubahan" pada masa depan. Dalam kegiatan ini akan dilakukan edukasi cuci tangan pakai sabun kepada siswa MI As'adiyah dalam bentuk penyuluhan di kelas dan dilanjutkan dengan simulasi di lapangan dengan berpedoman pada 6 langkah cuci tangan. Sebelum melakukan kegiatan ini siswa MI As'adiyah belum mengetahui cara mencuci tangan pakai sabun sehingga kegiatan ini dinggap berhasil $100 \%$ berhasil karena semua siswa dapat mempraktekkan mencucuci tangan menggunakan sabun dengan baik dan benar.
\end{abstract}

Kata Kunci: Edukasi; Cuci tangan pakai sabun; Pencegahan penyakit.

Abstract: School-age children have a habit or not paying attention to hand washing behavior, especially in the school environment. Hand washing with soap habit is still the world's attention because it is still found that people still forget to do hand washing behavior. The focus of CTPS activities is school children as "agents of change" in the future. In this activity education will be carried out washing hands with soap to MI As'adiyah students in the form of counseling in class and followed by simulation in the field guided by the 6 steps of hand washing. Before doing this activity MI As'adiyah students did not know how to wash their hands use the soap so this activity could be $100 \%$ successful because all students could practice washing hands with soap properly and correctly.

Keywords: Education; hand washing behavior with soap; Disease prevention.

\begin{tabular}{|c|c|c|}
\hline 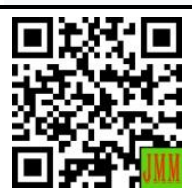 & $\begin{array}{l}\text { Article History: } \\
\text { Received: } 23-01-2020 \\
\text { Revised : } 10-02-2020 \\
\text { Accepted: } 15-02-2020 \\
\text { Online : } 02-03-2020 \\
\end{array}$ & $\begin{array}{r}\text { (C) () } \\
\text { This is an open access article under the } \\
C C-B Y \text {-SA license }\end{array}$ \\
\hline
\end{tabular}




\section{A. LATAR BELAKANG}

Sekolah sebagai lembaga yang memiliki organisasi yang meiliki kurikulum sebagai bentuk aktivitas yang direncanakan dan disusun dengan rapi (Nurochim, 2019). Pendidikan Kesehatan (PENKES) diberikan kepada anak dengan tujuan meningkatkan kebiasan hidup sehat sehingga dapat dipertanggung jawabkan pada diri sendiri dan lingkungannya juga ikut serta pada kegiatan yang berhubungan dengan kesehatan (Mardhianti, 2013), (Rindafit, 2015). Adapun tujuan pelaksanaan pendidikan kesehatan adalah memberikan informasi mengenai prinsip hidup sehat, menumbuhkan sikap dan perilaku hidup sehat serta membentuk kebiasaan untuk hidup sehat (Fitriani, 2011 dikutip oleh Apriany, 2012), (Juliawan, Mirayanti, \& Parwati, 2019).

Perilaku Hidup Bersih dan Sehat (PHBS) pada lingkungan sekolah merupakan cara agar siswa, guru dan masyarakat di lingkungan sekolah diberdayakan untuk mengetahui, berkeinginan dan bisa menjalankan PHBS serta ikut berpartisipasi dalam menciptakan lingkungan sekolah yang sehat. Menurut (Depkes RI, 2008), (Khumayra \& Sulisno, 2012), pada institusi pendidikan/sekolah yang dijadikan sebagai indikator PHBS adalah; mencuci tangan menggunakan sabun dan air mengalir, membeli makanan sehata yang terdapat di kantin, memakai WC yang sehat dan bersih, olahraga yang terukur dan teratur, membersihkan jentik nyamuk, tidak merokok di sekolah, mengukr berat dan tinggi badan serta membuang sampah pada tempatnya (Berot, 2017).

Salah satu cara masuknya bakteri dari udara maupun debu ke dalam tubuh anak yakni melaui tangan. Kotoran manusia, hewan atau cairan tubuh (contoh: ingus) yang bersentuhan langsung dengan tangan dapat menjadi media berpindahnya parasit seperti bakteri dan virus ke dalam tubuh manusia. Akibatnya, banyak penyakit yang bersarang di dalam tubuh dan untuk mencegahnya melalui tindakan cuci tangan menggunakan sabun (Detik Health, 2011 dikutip oleh Diah Nur Anisa, 2012)

Budaya cuci tangan belum diterapkan sepenuhnya oleh masyarakat Indonesia. Kebiasan yang terlihat bahwa mencuci tangan dengan sabun justru dilakukan setelah makan. Idealnya perilaku tersebut dilakukan sebelum makan agar mengurangi bakteri pada tangan (Pauzan \& Fatih, 2017). Di Indonesia telah digelar kembali hari cuci tangan pakai sabun pada tanggal 15 Oktober 2008 sebagai implementasi dari paradigma baru dari program kesehatan.

Mencuci tangan dengan sabun merupakan upaya pencegahan sebagai perlindungan tubuh dari berbagai penyakit yang sifatnya menular. Mencuci tangan dengan sabun dapat dilakukan ketika selesai BAB dan BAK, sebelum makanan disiapkan, sebelum dan sesudah mengkonsumsi makanan, sehabis bermain pada anak, setelah batuk atau bersin serta setelah membuang ingus (Desiyanto \& Djannah, 2013). Studi oleh (Purwandari, Ardiana, \& Wantiyah, 2013) memperlihatkan adanya 
signifikansi hubungan perilaku cuci tangan dengan insiden diare. Sedangkan studi (Rifai, Wahab, \& Prabandari, 2016) juga memperlihatkan ibu yang tidak mencuci tangan berpeluang 6,6 kali menyebabkan diare pada anak mereka dibandingkan dengan ibu yang tidak melakukan cuci tangan dengan sabun.

MI As'adiyah Pengkendekan merupakan sekolah swasta yang terletak di Jln. Masjid Nurul Wahyu Ilahi Desa Pengkendekan Kabupaten Luwu Utara yang berada dibawah naungan Kementerian Agama. Sekolah ini telah terakreditasi pada tahun 2018 dengan no SK : 110/SK/BANP-SM/XII/2018. Berdasarkan hasil survey yang dilakukan di lokasi terdapat siswa yang tidak mencuci tangan menggunakan sabun sebelum makan pada air yang tidak mengalir. Oleh karena itu edukasi perilaku cuci tangan pakai sabun perlu dilakukan untuk menghindari angka kesakitan yang timbul akibat bakteri yang menempel ditangan. Berdasarkan latar belakang tersebut maka dilakukanlah kegiatan pengabdian kepada masyarakat dalam bentuk "Edukasi Perilaku Cuci Tangan Pakai Sabun" pada siswa di MI As'adiyah Pengkendekan". Dalam kegiatan ini dilakukan penyuluhan tentang cara cuci tangan pakai sabun yang baik dan benar untuk menghindari masuknya bakteri ke dalam tubuh yang menempel pada tangan. Hal ini perlu dilakukan mengingat pengetahuan siswa tentang mencuci tangan yang baik dan benar mendorong kesadaran meningkatkan dan kesehatannya melalui PHBS.

\section{B. METODE PELAKSANAAN}

Kegiatan diikuti oleh 20 orang siswa MI As'adiyah Pengkendekan. Pelaksanaan kegiatan "Edukasi Perilaku Cuci Tangan Pakai Sabun" dilaksanakan melalui beberapa kegiatan, sebagai berikut :

\section{Tahap Survey Lokasi}

Tujuan kegiatan ini untuk mengetahui jumlah siswa yang memungkinkan menjadi peserta kegiatan serta mengamati perilaku cuci tangan yang dilaksanakan oleh siswa di sekolah tersebut. Selain itu dilakukan kontrak waktu dengan pihak sekolah untuk menentukan tanggal pelaksanaan kegiatan.

\section{Tahap Penyuluhan}

Kegiatan ini dilakukan di ruangan kelas dengan mengajarkan cara cuci tangan pakai sabun kemudian diikuti oleh semua peserta yang hadir. Menurut WHO, terdapat 6 cara melakukan cuci tangan yang benar yaitu: (1) menuangkan handwash pada telapak tangan kemuddian mengusap danmenggosok kedua telapak tangan dengan lembut dengan arah memutar; (2) mengusap dan menggosok kedua punggung tangan secara bergantian; (3) menggosok sela-sela tangan hinggah bersih; (4) membersihkan semua ujung jari secara bergantian dengan posisi saling mengunci; (5) menggosok dan memutar kedua ibu jari secara bergantian; (6) meletakkan ujung jari 
ke telapak tangan kemuadian menggosok secara perlahan (Sugiarto, Berliana, Yenni, \& Wuni, 2019).

\section{Tahap Simulasi}

Kegiatan ini dilaksanakan diluar kelas dengan melasanakan praktik cuci tangan pakai sabun dibawah air mengalir. Semua peserta mempraktekkan harus mempraktekkan dengan benar dalam pendampingan tim.

\section{HASIL DAN PEMBAHASAN}

Kegiatan pengabidan masyarakat dalam bentuk "Edukasi Perilaku Cuci Tangan Pakai Sabun" masih jarang dilakukan khususnya di MI As'adiyah Pengkendekan. Adapun hasil (output) yang diharapkan dari kegiatan ini adalah :

\section{Tahap Survey}

Dari hasil survey awal ditemukan masih terdapatnya siswa yang mencuci tangan sebelum makan tanpa menggunakan air mengalir dan memakai sabun. Solusi yang ditawarkan ke pihak sekolah untuk memperbaiki perilaku ini adalah melakukan kegiatan sebagai sosialisasi dengan memberikan penyuluhan dan simulasi cuci tangan pakai sabun. Pada tahap ini dilakukan pengurusan izin ke pihak sekolah kemudian menetapkan waktu pelaksanaan dan sepakati melaksanakan kegiatan tersebut.

2. Tahap Penyuluhan

Kegiatan dimulai pagi hari di ruangan kelas MI As'adiyah Pengkendekan. Kegiatan Penyuluhan seperti terlihat pada Gambar 1.

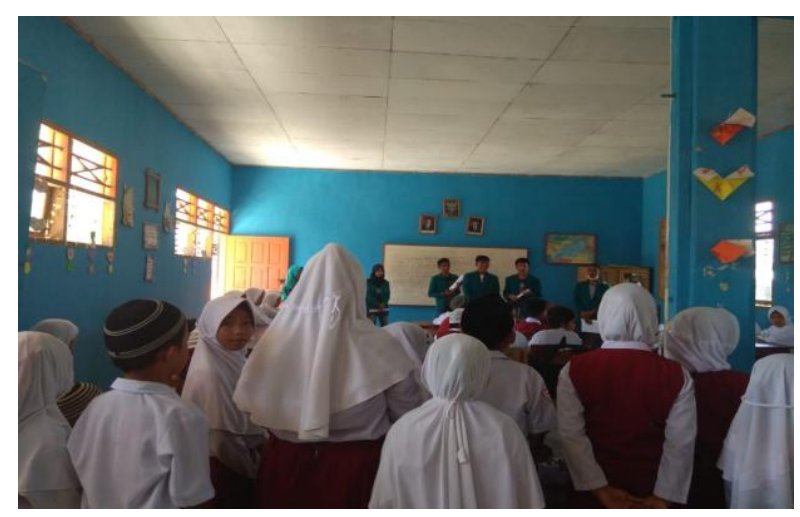

Gambar 1. Pendidikan Kesehatan Mencuci Tangan Menggunakan Sabun

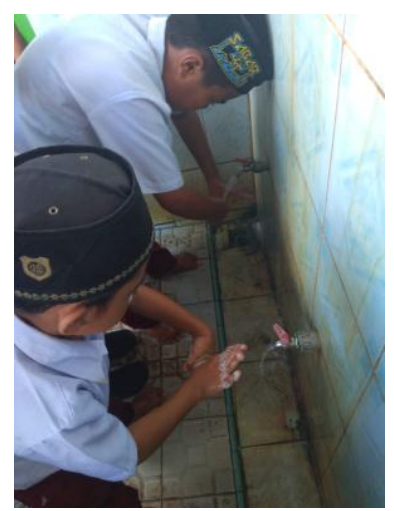

Gambar 2. Simulasi Kegiatan Mencuci Tangan Dengan Sabun

Penyuluhan kesehatan adalah kegiatan yang dilaksanakan melalui penyebaran pesan, penguatan keyakinan yang akan membuat masyarakat sadar, tahu dan memahami serta memiliki kemauan juga kemampuan melakukan suatu anjuran yang ada hubungannya dengan kesehatan (Septalia, 2010 dikutip oleh Wati, 2011). 
Kegiatan penyuluhan dilakukan dengan memberikan materi terkait tujuan cuci tangan, manfaat cuci tangan, dampak jika tidak mencuci tangan serta langkah-langkah cuci tangan pakai sabun. Tim pengabdian mempraktekkan langkah cuci tangan pakai sabun kemudian siswa diminta untuk mengikuti kegiatan tersebut. Tim pengabdian juga memperlihatkan alat serta bahan yang akan digunakan pada simulasi kegiatan tersebut.

3. Tahap Simulasi

Setelah melakukan penyuluhan di kelas maka kegiatan dilanjutkan dengan simulasi cara cuci tangan memakai sabun dibawah air mengalir yang dilaksanakan diluar kelas. Simulasi ini dilakukan oleh tim pengabdian masyarakat dengan berpedoman pada 6 langkah mencuci tangan. Satu per satu siswa didampingi untuk mencuci tangan memakai sabun sampai mereka mampu melakukan dengan baik dan benar. Kegiatan ini terlihat pada Gambar 2 di atas.

Kegiatan simulasi Cuci Tangan Pakai Sabun (CTPS) adalah serangkaian kegiatan berisi praktik tentang cara melakukan cuci tangan yang baik dan benar memakai sabun. Melalui kegiatan simulasi ini anak sekolah dapat memperoleh pengetahuan dan teknik cuci tangan yang benar. Simulasi ini diharapkan dapat menekan angka kejadian penyakit pada anak sekolah seperti diare dan kecacingan akibat bakteri yangmasuk kedalam tubuh ketika anak tidak mencuci tangan (Angelia, Novita sary, \& Handayani, 2019).

\section{SIMPULAN DAN SARAN}

Melalui pelaksanaan kegiatan pengabdian masyarakat di MI As'adiyah Pengkendekan dapat disimpulkan bahwa kegiatan ini secara umum dapatmeningkatkan pengetahuan siswa tentang tujuan cuci tangan, manfaat cuci tangan, dampak yang dapat ditimbulkan jika tidak mencuci tangan serta langkah-langkan mencuci tangan menggunakan sabun yang baik dan benar. Dalam pelaksanaan di lapangan para peserta yakni siswa MI As'adiyah Pengkendekan memberikan respon yang baik dan antusias yang tinggi dalam mengikuti penyuluhan dan simulasi cuci tangan pakai sabun.

Pihak sekolah diharapkan dapat memantau kegiatan para siswa yang memerlukan pentingnya cuci tangan pakai sabun sehingga mikroorganisme dari tangan dapat tidak masuk ke dalam tubuh sehingga derajat kesehatan siswa akan semakin meningkat.

\section{UCAPAN TERIMA KASIH}

Ucapan terima kasih kepada pihak yang telah memberikan kontribusi pada pelaksanaan kegiatan ini sehingga dapat berjalan dengan baik sesuai perencanan. Tim penulis mengucapkan terima kasih kepada Lembaga Penelitian dan Pengabdian Pada Masyarakat (LPPM) Stikes Kurnia Jaya Persada Palopo yang telah membantu pendanaan kegiatan pengabdian ini 
sehingga terlaksana dengan baik. Ucapan terima kasih juga kami sampaikan kepada kepala MI As'adiyah yang telah memberikan waktu kepada kami melaksanakan kegiatan ini dan kepada para siswa atas antusias yang tinggi mengikuti kegiatan ini sampai selesai.

\section{DAFTAR RUJUKAN}

Apriany, D. (2012). Perbedaan Perilaku Mencuci Tangan Sebelum Dan Sesudah Diberikan Pendidikan Kesehatan Pada Anak Usia 4-5 Tahun. Soedirman Journal of Nursing, 72), 60-66.

Berot, F. H. (2017). Faktor Yang Berhubungan Dengan Perilaku Hidup Sehat Rumah Tangga Di Kelurahan Kubu Dalam 2016. UNES Journal of Social And Economics Research, 2(2), 195. https://doi.org/10.31933/ujser.2.2.195-207.2017

Depkes RI. (2008). No Title. (Rumah Tangga Berperilaku Hidup Bersih dan Sehat).

Desiyanto, F. A., \& Djannah, S. N. (2013). Efektivitas Mencuci Tangan Menggunakan Cairan Pembersih Tangan Antiseptik (Hand Sanitizer) Terhadap Jumlah Angka Kuman. Jurnal Kesehatan Masyarakat (Journal of Public Health), 7(2), 75-82. https://doi.org/10.12928/kesmas.v7i2.1041

Diah Nur Anisa. (2012). Pengaruh pendidikan kesehatan terhadap perilaku cuci tangan pakai sabun pada anak usia sekolah di SD 2 Jambidan Banguntapan Bantul. 6-15.

Juliawan, D. G., Mirayanti, N. K. A., \& Parwati, N. A. (2019). Pengaruh Pendidikan Kesehatan Dengan Bernyanyi Lagu Cuci Tangan Terhadap Tindakan Mencuci Tangan Anak Prasekolah. Journal Center of Research Publication in Midwifery and Nursing, 3(1), 11-20. https://doi.org/10.36474/caring.v3i1.124

Khumayra, Z. H., \& Sulisno, M. (2012). Perbedaan Pengetahuan Dan Sikap Perilaku Hidup Bersih Dan Sehat (Phbs) Antara Santri Putra Dan Santri Putri. Jurnal Keperawatan Diponegoro, 1(1), 197-204.

Mardhianti, R. (2013). Pesan Kesehatan: Perilaku Hidup Bersih Dan Sehat (Phbs) Anak Usia Dini Dalam Kurikulum Pendidikan Anak Usia Dini. Jurnal Ilmiah Kesehatan, 2(3). https://doi.org/10.35952/jik.v2i3.71

Nurochim, N. (2019). Pemberdayaan Masyarakat Rural Melalui Pendidikan (Pelatihan Aplikasi Strategi Pembelajaran Kurikulum 2013 ABAD 21). JMM (Jurnal Masyarakat Mandiri), 126. https://doi.org/10.31764/jmm.v0i0.1344

Pauzan, P., \& Fatih, H. Al. (2017). Hubungan Pengetahuan Dengan Perilaku Cuci Tangan Siswa Di Sekolah Dasar Negeri Cicadas 2 Kota Bandung. Jurnal Keperawatan BSI, 5(1), 18-23. https://doi.org/10.31311/.V5I1.1458

Purwandari, R., Ardiana, A., \& Wantiyah. (2013). Hubungan antara perilaku mencuci tangan dengan insiden diare pada anak usia sekolah di kabupaten jember. Jurnal Keperawatan, 4, 122-130.

Rifai, R., Wahab, A., \& Prabandari, Y. S. (2016). Kebiasaan cuci tangan ibu dan kejadian diare anak: studi di Kutai Kartanegara. Berita Kedokteran Masyarakat, 32(11), 409-414.

Rindafit, R. (2015). Efektifitas Pendidikan Kesehatan Terhadap Praktik Cuci Tangan Pada Anak Prasekolah Di Paud Darunnajah Tamansari Wuluhan Jember. KTI D3 KEPERAWATAN.

Sugiarto, S., Berliana, N., Yenni, M., \& Wuni, C. (2019). Peningkatan Pengetahuan Siswa tentang Cuci Tangan yang Baik dan Benar di SDN 37/I Kecamatan Bajubang. Jurnal Pengabdian Harapan Ibu (JPHI), 1(2), 59. https://doi.org/10.30644/jphi.v1i2.266

Wati, R. (2011). Pengaruh pemberian Penyuluhan PHBS Tentang Mencuci Tangan Terhadap Pengetahuan Dan Sikap Mencuci Tangan Pada Siswa Kelas V Di SDN Bulukantil Surakarta. In Perpustakaan UNS. 